\title{
Sciendo
}

10.2478/topling-2019-0006

\section{Discourse studies: Between social constructionism and linguistics. A critical overview}

\author{
Piotr Cap* \\ University of Social Sciences, Lodz, Poland
}

\begin{abstract}
This paper gives a critical overview of the analytical approaches dominating the field of discourse studies in the last three decades, from the perspective of their philosophical and formative bases: social constructionism and linguistics. It explores different conceptions of the theoretical nexus between these two bases leading to the emergence of three distinct yet complementary strands of thought (i-iii). The paper starts with poststructuralist views of discourse salient in (i) Laclau and Mouffe's Discourse Theory. Laclau and Mouffe's assumption that no discourse is a closed entity but rather transformed through contact with other discourses is taken as the introductory premise to present a large family of (ii) critical discourse studies, characterized as text-analytical practices explaining how discourse partakes in the production and negotiations of ideological meanings. Finally, the paper discusses (iii) three recent discourse analytical models: Discourse Space Theory, Critical Metaphor Analysis and the Legitimization-Proximization Model. These new theories take a further (and thus far final) step towards consolidation of the social-theoretical and linguistic bases in contemporary discourse studies. The empirical benefits of this consolidation are discussed in the last part of the paper, which includes a case study where the new models are used in the analysis of Polish anti-immigration discourse.
\end{abstract}

\section{Key words}

discourse studies, critical discourse studies, social constructionism, social theory, linguistics

\section{Introduction}

At the most general level, discourse studies can be characterized as ways of exploring the meanings produced by language use and communication, the contexts and processes of these meanings, and practices caused by these meanings (Jørgensen and Phillips, 2002; Unger, 2016; Fetzer, 2018). Discourse studies as research practices are essentially trans-disciplinary and include different theoretical starting points and discipline-specific applications. Some of these variations stress, for example, coherent and strict analysis of language, conversation and interaction (Golato and Golato, 2018). Other variations emphasize intertextuality of meanings and the relationship of genres and discourses in an interaction situation or in a broader historical and social situation or process (Wodak, 2011; Wodak and Meyer, 2016). Whatever the focus, a typical discourse study combines the analysis of language use at the micro level and the analysis of social situations at the macro level. Thus, regardless of the specific orientation of discourse research, the common factors uniting the analytical variations are their common philosophical bases: social constructionism and linguistics. This paper explores some different conceptions of the theoretical nexus between these two bases which have led to the emergence of three distinct yet eventually complementary strands of thought dominating the field of discourse studies in the last 35 years. These are: (a) Laclau and Mouffe's (1985) classical discourse theory and its concept of "discursive struggle", (b) the vast and complex family of critical discourse studies (see overviews in

\footnotetext{
* Address for correspondence: Piotr Cap, University of Social Sciences, Sienkiewicza 9, Lodz, Poland. E-mail: piotr.cap@gmail.com
} 
Hart and Cap, 2014; Wodak and Meyer, 2016; Flowerdew and Richardson, 2018), and, emerging from the latter group, (c) recent cognitive-pragmalinguistic models such as Discourse Space Theory (DST; Chilton, 2004, 2014), Critical Metaphor Analysis (CMA; Goatly, 2007; Charteris-Black, 2005; Musolff, 2016), and the Legitimization-Proximization Model (LPM; Cap, 2013, 2017a).

Naturally enough, the selection of analytical models in the present paper cannot do full justice to the immense amount of work in discourse studies, and many other mappings are certainly possible. In a major attempt to take stock of the field, Angermuller et al. (2014) characterize discourse studies as not only a trans-disciplinary project but rather "one which runs counter to the division of knowledge into specialized disciplines and sub-disciplines" (ibid, p. 2). Further, reflecting different scientific and intellectual traditions, discourse studies reveal different analytical orientations (theoretical vs empirical), methods (qualitative vs quantitative) and, not least, different types of data utilized by researchers. All these variations pose a huge classificatory and typological challenge, making it difficult to draw distinctions between the particular discourse models, theories and their empirical foci (Jørgensen and Phillips, 2002). As a result, all such attempts remain quite arbitrary, though as Angermuller et al. (2014) observe, the methodological and theoretical perspectives are perhaps easier to grasp than the objects and discourse phenomena that they extend over (ibid, p. 11). That said, Angermuller et al. (2014) scrutinize the major approaches which have developed since the 1960s in France, Britain, Germany and the USA, identifying some consecutively emerging, relatively well-demarcated trends such as philosophicalpoststructuralist, interactional, enunciative-pragmatic, sociopragmatic, discourse-historical and critical. This classificatory attempt is laudable and proves that even in such a heterogeneous field as discourse studies, certain typological mappings are possible, especially if there is a controlling category which defines the domain and range of the proposed distinction(s). Such a stance seems to comply with another major mapping of the field, by Unger (2016), who shows how the main theoretical perspectives in critical discourse studies can be positioned within an interdisciplinary space defined by cognitive, textual and social categories (though the choice of these categories remains arbitrary).

Recognizing the above possibilities as well as the constraints, this paper aims to propose another dimension in which discourse studies can be accounted for. It involves, broadly speaking, the relation of social theory to linguistic analysis in discourse research, and a gradual merger and consolidation of the two inputs triggered by the growing presence of the linguistic element. Building on this premise, the present discussion is meant as an overview of the most seminal theories (where some models, such as that of Laclau and Mouffe, serve to reflect a whole research tradition) and approaches which, first of all, share the starting point that people's ways of talking do not neutrally reflect our world, identities and social relations but, rather, play an active role in creating and changing them. This characterization can be described as synchronic and individual; it applies to each of the models included regardless of when they were proposed, how they were looked at then, and how they are considered now. Yet there is another, more distinctive, diachronic and collective characterization, which responds to the aims of the present paper in the most evident and productive way. Taken together, the selected approaches demonstrate a steady evolution of the mind-set of discourse researchers with regard to three central ontologies in discourse philosophy: discourse as text, discourse as discursive practice, and discourse as social practice (Fairclough, 1992). The first stems from the theory of semiotics developed by Saussure (1966) and Halliday (1978), hence, the focus is mostly on linguistic features of discourse. These include word patterns, cohesion, text structure, use of direct/indirect speech, etc. (Blommaert and Bulcaen, 2000); analysis of these features in discourse defines "a framework for analysing texts which covers aspects of their production and interpretation as well as formal properties of text" (Fairclough, 1992). The second ontology involves processes of text production, distribution and consumption. At this level of analysis, researchers aim to answer questions related to the historicity, intertextuality and interdiscursivity of the discourse (Breeze, 2011). The third ontology links the linguistic side of discourse with the social side; it involves notions of ideology (Althusser, 1971), hegemony and consent (Gramsci, 1973), power and knowledge (Foucault, 1971), and linguistic capital (Bourdieu, 1992). These concepts define the focus on discourse as an instrument to represent, evaluate, argue for and against, and ultimately to legitimate or delegitimate social actions. In respect of the latter, discourse thus functions in creating, sustaining and/or transforming the social status quo (Hart and Cap, 2014).

The three schools of thought included in the present paper reveal, collectively, a gradual consolidation of these different discourse ontologies. As such, they document the advancing merger of social theory and linguistic analysis in discourse studies. It is argued that, over the years, discourse 
studies have taken an essentially linguistic turn, exploring discourse social facets in terms of strictly linguistic features such as recurrent lexical patterns and grammatical configurations. In what follows, we start (section 2) from early poststructuralist approaches, focusing upon Laclau and Mouffe's (1985) discourse theory and their concept of "discursive struggle" - a struggle of particular ways of talking of and understanding the world in an attempt to achieve discursive and social hegemony. Acknowledging the continuity of discursive struggle, Laclau and Mouffe formulate the assumption that no discourse is a closed entity but rather transformed through contact with other discourses. It is argued that this assumption can be taken as the founding premise for the emergence, in the last 30 years, of a large and complex network of critical discourse studies (section 3). Critical discourse studies (CDS) can be characterized (Hart and Cap, 2014; Flowerdew and Richardson, 2018) as a hub of text-analytical practices that work on the link between language and social reality from the perspective of power and empowerment, showing how discourse partakes in the production, change and negotiations of ideologically charged meanings. The discussion in section 3 demonstrates that although contemporary critical discourse studies draw heavily upon classical discourse theories such as Laclau and Mouffe's, they still can (and should) be regarded as distinctive endeavours, geared toward text-based, systematic de-mystification of ideologies coded in discourse by lexical and grammatical means. The research output of critical discourse studies is huge, making some theories blend with others (Wodak and Meyer, 2016) or, conversely, emerging as fully fledged trans-disciplinary models equipped to deal with a large spectrum of discourse data in multiple domains. Thus, in section 4 the paper discusses three such models belonging initially to the cognitive-psychological strand of critical discourse studies, yet now functioning as self-contained discourse theories with their own methods and tools of analysis. These models are Discourse Space Theory (DST), Critical Metaphor Analysis (CMA), and the LegitimizationProximization Model (LPM). Section 4 describes the common features of these theories, as well as differences in their conceptual framework, scope and analytical methods. Finally, research tools provided by the three models are applied in a case study of contemporary populist discourse. Specifically, they are used in a brief discourse analysis of Polish anti-immigration rhetoric.

\section{Classical approaches: Laclau and Mouffe's discourse theory}

Why start with Laclau and Mouffe? The Discourse Theory (DT) of Ernesto Laclau and Chantal Mouffe seems, more than any other approach, a telling specimen and reflection of the interrelations between the multiple perspectives and strands of thought underlying early poststructuralist discourse studies. It is commonly associated with Laclau and Mouffe's book Hegemony and Socialist Strategy (1985), as well as other works written by Laclau or Mouffe individually (Laclau, 1990, 1993, 1996; Mouffe, 1993; among others). It can be characterized, at its most fundamental level, as a combination of post-Marxist social thought and post-Saussurian linguistics, which Laclau and Mouffe fuse together into a single allencompassing model of the social world. Drawing on the notions of hegemony and consent by Gramsci (1973), and Althusser's (1971) concept of ideological struggle, it argues that dominant classes within society engage in discourse processes to manufacture popular consent for the unequal distribution of power and wealth. In so doing, they exercise their social and discursive hegemony, which involves, for the most part, defining and upholding social structures and groups. The different groups that exist in society are thus all the result of political, discursive processes - politics has primacy, as Laclau (1990, p. 33) describes. This is not to say, of course, that external reality does not exist. However, our perception of reality and of the character of real objects is mediated entirely by discourse. We, as human beings, enter a world already composed of discourses and cannot conceive of objects outside it. For this reason, the discursive and non-discursive worlds cannot be separated (Laclau and Mouffe, 1985, p. 66). As stated by Laclau and Mouffe:

The fact that every object is constituted as an object of discourse has nothing to do with whether there is a world external to thought, or with the realism/idealism opposition. An earthquake or the falling of a brick is an event that certainly exists, in the sense that it occurs here and now, independently of my will. But whether their specificity as objects is constructed in terms of 'natural phenomena' or 'expressions of the wrath of God', depends upon the structuring of a discursive field. What is denied is not that such objects exist externally to thought, but the rather different assertion that they could constitute themselves 
as objects outside any discursive conditions of emergence. (Laclau and Mouffe, 1985, p. 108)

As evidenced by the above argument, Laclau and Mouffe's theory can in many ways be regarded as an embodiment and synthesis of the early poststructuralist work in discourse research (Breeze, 2011). Recognizing the absence of any overarching unifying principle of discourse, it echoes Foucault's (1972) famous "regularity in dispersion", an idea that it is discourse itself, "the structuring of a discursive field", where we find specific rules concerning the functioning of discursive elements, i.e. some regularities which are not at all limited to language relations. This idea complies, in turn, with Derrida's (1970) or Lacan's (2007) critique of the structural approach to language, such as rejecting the view of language as a closed system, as well as the idea of strict isomorphism between the order of the signified and that of the signifier which stems from Saussure's theory. A natural consequence of such a standpoint is recognition of the historical character of discursive formation, which is a point made both in Laclau and Mouffe's (1985) and Foucault's (1972) writings, however with a different emphasis. While Foucault writes quite generally about the existence of a "historical a priori", Laclau and Mouffe go on to claim that discourse theory can be included into the "transcendental turn" in philosophy, but only with the restriction that "discursive a priori forms" are historically dependent. Altogether, the Discourse Theory of Laclau and Mouffe reveals many more connections to (or reflections of) the poststructuralist work in the 1960s and 1970s - far more than can be discussed within the confines of this paper. A particularly intriguing one is the adoption of the Bakhtinian (1981) concept of dialogue and its relevance to political (discourse) theory. Interestingly, Laclau and Mouffe do not find dialogue incongruent with the idea of "discursive struggle" underlying DT; conversely, they consider it instrumental in building a nonconsensual notion of discursively formed democracy. Democracy then is seen as a complicated set of conversations that do not necessarily lead to a social consensus but could still promote better understanding between all participants in the socio-political struggle.

For a discourse researcher, the most crucial aspect of Discourse Theory is the idea that, since all social phenomena are mediated through discourse, their meanings can never be permanently fixed. A broad array of discourses, each structuring reality in a different way, compete to define what is "true" within a particular aspect of the social world. People's understanding of these aspects (often termed "terrains" or "domains" in Laclau and Mouffe's work) is contingent upon the ongoing struggle between discourses, with perceptions of society and identity always open to newly emerging representations as meanings are constantly altered and reconfigured through contact with competing discourses. The essence of discourse analysis, then, is not to discover the "truth" about reality (for example, to find out which groups exist within a society) but, rather, to describe how discursive struggle constructs this reality (for example, how people and groups perceive their identity within a society) so that it appears natural and neutral. This idea brings Discourse Theory quite close, once again, to the genealogical work of Foucault, who argues (Foucault, 1972) that the task of the genealogist is to immerse themselves in the myriad power struggles that shape historical forms of discourse.

Phillips and Hardy (2002) offer an illuminating discussion of how discourses compete (or "struggle", in Laclau and Mouffe's (1985) parlance) to define different representations in line with the interests of their producers. The example they work with is that of a flood associated with a river overflowing its banks. The rise in the water level that leads to the flood is, they begin, a physical event that takes place independently of people's thoughts and talk. Indeed, everybody drowns if they are in the wrong place, irrespective of what they think or say - the rise in the water level is a material fact. But, as Phillips and Hardy note, the moment people try to ascribe meaning to it, it is no longer outside discourse. Most would place it in the category of "natural phenomena", but they would not necessarily describe it in the same way. Some would draw on a meteorological discourse, attributing the rise in the water level to an unusually heavy downpour. Others might account for it in terms of the El Niño phenomenon, or see it as one of the many global consequences of the "greenhouse effect". Still others would see it as the result of "political mismanagement", such as the national government's failure to commission and fund the building of dykes. Finally, some might see it as a manifestation of God's will, attributing it to God's anger over a people's sinful way of life or seeing it as a sign of the arrival of Armageddon. The rise in the water level, as an event taking place at a particular point in time, can, then, be ascribed meaning in terms of many different perspectives or discourses. Phillips and Hardy (2002) observe that these different and competing discourses each point to different and competing courses of action as possible 
and appropriate, such as the construction of dykes, the organization of political opposition to global environmental policies or the state government, or preparation for the imminent Armageddon. This demonstrates that the ascription of meaning in (competing) discourses works to impact the future or unfolding course of events.

Phillips and Hardy's (2002) argument shows that in Laclau and Mouffe's DT language is not merely a channel through which information about underlying mental states and behaviour or facts about the world are communicated. On the contrary, language is a "machine" that generates, and as a result constitutes, the entire social world. This also extends to the constitution of social identities and social relations. It means that changes in discourse are an instrument by which the social world is changed. Struggles at the discursive level take part in changing, as well as in reproducing, social reality.

Although, unlike its conceptual successors under the CDS banner, Discourse Theory has never aimed to prescribe specific domains where these theoretical claims could be operationalized and researched, one cannot overlook its implications for empirical projects involving essentially linguistic work. First of all, if language is structured in different discursive patterns, and discursive patterns are maintained and transformed in discursive practices in different social contexts where language is in action, then the meaning of a linguistic unit is not a universal category but rather a potential to materialize in a specific context, at the demand of the speaker. One context may sanction a lexical or grammatical choice that another context will not. Discourse, then, exhibits a dynamic relation between the functional and the linguistic side of communication. As over time speakers agree on what linguistic choices are the most effective in a given social situation, social functions are realized in an increasingly stable agglomeration of language form (word, phrase, utterance etc.). It is then the task of a discourse researcher to abstract and categorize these choices, assigning them to a context.

Also notably, Laclau and Mouffe's idea of the ongoing struggle between competing discourses and the resulting changes in world representations provides for a conception of meaning being reshaped while travelling through intertextual and interdiscursive (including multimodal) routes. This implication is of importance (as well as a challenge) to genre theory, which tries to attribute communicative function to the presence of recurrent formal features of genres such as specific word patterns, cohesion markers or text structure (Cap and Okulska, 2013). That is not always an unproblematic undertaking. Imagine a researcher attempting to theorize, a priori, upon the content and function of a political speech, just from its context (the speaker, topic, audience expectations) and the general expert knowledge he/she possesses. The task may look realistic at first, but imagine, further, that the speech is performed in a multimodal context involving music and image as accompanying modes (as in the famous "Yes we can" election video of Barack Obama). Are the standard methodological tools designed to work with political speeches still valid or, perhaps, is more data investigation necessary to update the conception of the principal genre (i.e. political speech)? If the latter, a new set of tools needs to be defined for multimodal political advertising that includes text as one of its ingredients and no longer the only one. Whatever the verdict, it cannot be reached without a linguistically focused analysis: a formal inquiry into the lexical distinctive features of the principal genre missing from the new genre.

Finally, and in direct relevance to the CDS research described in the next section, Laclau and Mouffe's Discourse Theory goes a long way towards providing the discourse analyst with a task (or even a mission) to deal with mystifying, persuasive and manipulative powers of discourse. This is not (just) because it presupposes a constitutive role of discourse in sanctioning asymmetries of power and wealth. Not even because it brings together the notions of discursive hegemony and social hegemony. The most distinctive prompt comes from Laclau and Mouffe's recognition that a change in focus and perspective in discourse leads to a change in what aspect of reality becomes highlighted as true, correct, or otherwise preferred over other, equally valid, aspects. ${ }^{1}$ The big consequence is that just as the other aspects get hidden, so do ways in which to establish any counter-argument against the preferred view. If in the flood example the reasons are discussed on a solely meteorological plane, there is little way in which any mismanagement could be detected. And conversely, an excessively political focus of the debate is likely to brush aside many of the inherently environmental aspects. It is to DT's credit that it

\footnotetext{
${ }^{1}$ In that sense, DT is quite consistent with the conception of "highlighting and hiding" present in metaphor theory since Lakoff and Johnson's seminal publication of 1980. Yet, Laclau and Mouffe never mention metaphor as a strategic instrument for forcing such fragmentary conceptualizations.
} 
points to the role of discourse in creating such shifts, though it remains silent about what specific linguistic features of different discourses should be studied for a full picture.

\section{Critical Discourse Studies}

Implications of poststructuralist discourse theories are easily recognizable in Critical Discourse Studies (CDS), a self-conscious research movement bringing together scholars of linguistic, sociopsychological, political-scientific and other backgrounds (Jørgensen and Phillips, 2002). Interestingly, as Breeze (2011) observes, the specific inputs of the early discourse models such as DT are not always acknowledged directly by CDS authors, even if analytical connections are obvious. For instance, while in the discourse-historical strand of CDS such acknowledgements are numerous, the situation in the political research domain is quite different. There, scholars often refer to Foucault, Althusser or even Gramsci as the primary inspiration, and mentions of DT are somewhat less plentiful. There are arguments (such as e.g. Macgilchrist, 2014) which explain this asymmetry by pointing to the synthetic character of Laclau and Mouffe's DT model. Another explanation is that, compared to Foucault, DT carries a lower number of "key phrases" (such as, for instance, "discursive struggle"), which makes direct referencing slightly difficult, even if general influence remains huge (Macgilchrist, 2014). Given the fact that Laclau and Mouffe's theory includes, in one way or another, most of the views of discourse present in Foucault's writings, this point must certainly be agreed with.

That said, in the last three decades we see CDS firmly establishing itself as a field of practice within the humanities and social sciences, to the extent that the abbreviation "CDS" is widely used to denote a distinctive approach to language analysis manifested across a range of different disciplines (Breeze, 2011). In recent handbooks, CDS is characterized as a "transdisciplinary, text-analytical approach to critical social research" (Hart and Cap, 2014, p. 1; see also Wodak and Meyer, 2016; Flowerdew and Richardson, 2018). Of course, this basic characterization cannot possibly do justice to the vast body of work produced within the field of CDS. It captures, however, one property that is central to all CDS research: the commitment to a systematic, text-based exploration of language to reveal its role in the workings of ideology and power in society (Fowler, et al., 1979; Hodge and Kress, 1993; Fairclough, 1989, 1995; van Dijk, 1999; Wodak and Meyer, 2016; Wodak, 2012; among others). It is exactly this core feature that underlies any strand of CDS practice, making it a response to the lack of linguistic element in early discourse studies such as Laclau and Mouffe's.

Procedurally, CDS is not confined to any specific methodology or area of research. On the contrary - it is multifaceted, dealing with data of very different kinds and applying a broad spectrum of theories sourced from across the humanities, social and cognitive sciences (Hart and Cap, 2014; Wodak and Meyer, 2016; Flowerdew and Richardson, 2018). Hart and Cap (2014) note that, because of this heterogeneity, both the "discourse" and the "studies" in the CDS designation tend to mean something different to different analysts. We have seen from the overview of early discourse theories such as Laclau and Mouffe's DT that discourse is a multidimensional, multimodal and multifunctional phenomenon. It is produced with reference to different dimensions of context, such as linguistic, intertextual, historical and - notably for CDS practitioners - socio-cultural and political. Functionally, it is used to represent, evaluate, argue, counter-argue, and legitimate or delegitimate social actions. It shapes situations, institutions, and social structures, and is simultaneously shaped by them. Altogether, the many faces of discourse often preclude any uniform perception of how it can be investigated.

In CDS, differences in analytical predispositions are reflected conspicuously in the amount of space which different researchers devote to investigating the micro (linguistic) and macro (social) dimensions of discourse (Benke, 2000). Some analysts focus deductively on the macro-level social structures which facilitate or motivate discursive events, while others focus inductively on the micro-level, looking at the particular chunks of language that make up these events. These preferences are, of course, never mutually exclusive but are a matter of analytical emphasis. Furthermore, many researchers steer a middle, "abductive" course. In Luke's (2002) words:

CDS involves a principled and transparent shunting backwards and forth between the microanalysis of texts using various tools of linguistic, semiotic and literary analysis, and the macroanalysis of social formations, institutions and power relations that these texts index and construct. (Luke 2002, p. 100) 
The presence of abductive practice may be one of the ways in which to distinguish CDS from the classical discourse models of Laclau and Mouffe, Foucault, and others. Another one is the commitment of CDS to textual study involving linguistic tools and methods. Yet the most conspicuous difference between the classical theories and CDS lies in the word 'critical' in the CDS designation (Hart and Cap, 2014). This involves seeing CDS as a perspective, position or attitude, signposting a specific research agenda. The concept of critical in CDS, however, is understood in as broad a sense as the concept of discourse. For scholars working with a neo-Marxist notion of critique (Fairclough, 1992, 1995; Chouliaraki and Fairclough, 1999), critique presupposes a particular political stance on the part of the analyst and is intended to be instrumental in bringing about social change (Hart and Cap, 2014). This attitude is often contested by researchers both within (Luke, 2002; Martin, 2004) and outside (or halfoutside) the community of CDS (Widdowson, 1998, 2005; Chilton, 2005). Martin (2004) claims that it leads to the essentially "negative" nature of analysis, which thus overlooks positive and potentially transformative uses of discourse. In response, Martin and Rose (2003) propose "positive discourse analysis", encouraging critical scholars to devote more attention to the "discourse of positive change and discourse as the site of resistance" (2003, p. 36).

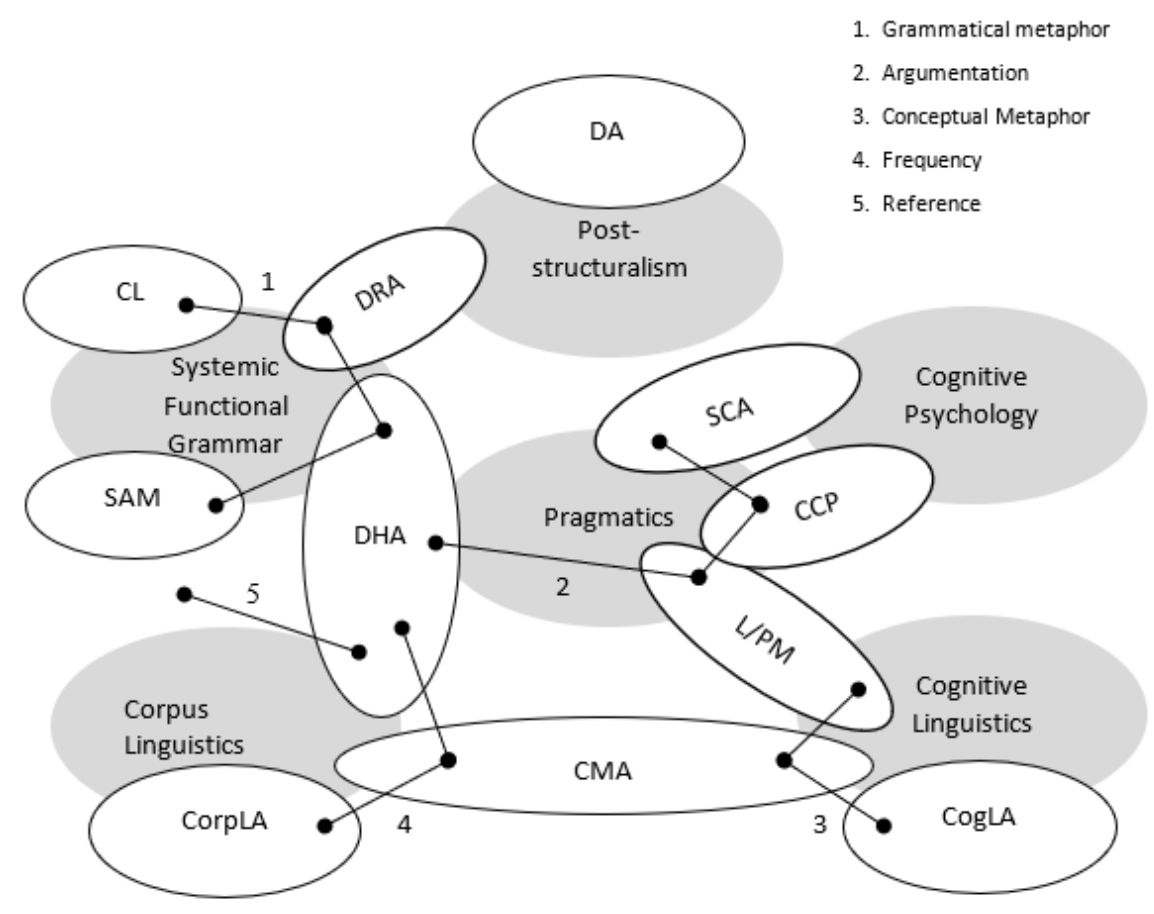

Figure 1. Contemporary CDS: Approaches and methodological attractors; CL: Critical linguistics; DRA: Dialectical-relational approach; DA: Dispositive analysis; SAM: Social actor model; DHA: Discourse-historical approach; SCA: Socio-cognitive approach; CCP: Critical cognitive pragmatics; L/PM: Legitimisation-proximisation model; CogLA: Cognitive linguistics approach; CMA: Critical metaphor analysis; CorpLA: Corpus linguistics approach (reproduced from Hart and Cap 2014, p. 7 [Figure 0.3])

For a growing number of CDS scholars today, however, critique comes not so much from a particular political perspective but is concerned more with mystification, linguistic coercion and other abuses of language per se, and the cognitive and linguistic mechanisms involved (Hart and Cap, 2014). Criticality, then, is a conspicuous feature and in a sense a necessary condition for defining CDS but it is not a sufficient condition. What sets CDS apart from other forms of discourse research is thus, on the one hand, its position and research agenda, and on the other, its focus on the micro-level analysis of texts, which are considered the prime source of attested data. As has been noted, in its analysis of texts and the choice of domains CDS relies primarily on the field of linguistics - though to different degrees in different approaches and works. In their recent attempt to take stock of the field, Hart and Cap (2014) 
distinguish eleven approaches in CDS. They position these main approaches in relation to their specific "methodological attractors", which indicate the underlying analytical traditions. Hart and Cap's (2014) outline is reproduced in Figure 1. The white ovals mark the approaches, and the shaded ovals mark their attractors. The five constellations in the figure demonstrate how different approaches are linked by common objects of analysis. The representation in Figure 1 illustrates the variety and interconnectedness of different research traditions in CDS. For example, the discourse-historical (Wodak, 2011; Reisigl and Wodak, 2001; etc.) and socio-cognitive (van Dijk, 2008) approaches are both related in their focus on argumentation, although the discourse-historical approach deals with argumentation in more detail, proposing tools to locate and describe fallacy triggers and argumentative topoi (van Eemeren and Grootendorst, 1992) in different discourse domains. At the same time, the discourse-historical approach borrows in its framework of "referential strategies" from the social actor model (Koller, 2004; van Leeuwen, 2005; etc.). In turn, the social actor model is presented as a grammar in the format of Halliday's functional network (Halliday, 1994). We thus observe direct as well as indirect connections between the particular models.

As Hart and Cap (2014) demonstrate, contemporary CDS is a genuine mix of social and linguistic theory, lending itself to different typological procedures. While different approaches can be mapped out according to the social theories they are influenced by, they may equally be distinguished by the linguistic fields and models that provide for their text-analytical methodologies. One model that has turned out particularly influential is Halliday's systemic functional grammar (Halliday, 1994), implementing analytic formalizations in much of the early CDS and in critical linguistics in particular (Wodak, 2011; Chilton, 2005). It has thus helped early theories of discourse such as Laclau and Mouffe's DT or critical linguistics (Fowler, et al., 1979; Fowler, 1991; Hodge and Kress, 1993), to retain their central role in the development of CDS. As for critical linguistics, it is often considered (Fairclough and Wodak, 1997) more than a historical precursor to CDS. Influenced over years by text-analytical frameworks such as systemic functional grammar, it has been able to upgrade its tools to produce comprehensive, qualitative-quantitative studies (Hart and Cap, 2014; Flowerdew and Richardson, 2018). As a result, it can be seen as a major approach in the landscape of modern CDS (Fairclough and Wodak, 1997).

Notwithstanding the revisions of older theories, CDS has grown considerably in the last years to develop several completely new schools. This rapid expansion can be understood as a response to recent advances in linguistics and other communication sciences. The nature of this response is, first of all, that such advances make it possible to address and, in many cases, offset certain criticisms raised against CDS. Second, modern developments in linguistics and communication science provide new tools to better capture and document the ideological potential of discourse. Third, there are new frameworks being developed or refined to account for newly formed genres, such as, recently, genres of computer mediated communication (Giltrow and Stein, 2009; Yus, 2011). One major development in linguistics that CDS has incorporated almost immediately is, undoubtedly, corpus studies (Stubbs, 2002, 2004; Partington, 2006; Baker, 2006; Baker, et al., 2008; O’Halloran, 2010). Hart and Cap (2014) argue that the corpus linguistic approach in CDS helps answer criticisms pertaining to possible bias in data selection and to the statistical value of findings (Stubbs, 1997). It is, however, not just a "problem solver" which can be applied together with other approaches to preclude subjectivity and overgeneralization (Wodak and Meyer, 2009). As noted recently by Flowerdew and Richardson (2018), the corpus linguistic approach brings its own unique analytical techniques, such as collocation and prosody analysis, which have been more and more productive in studying set chunks of texts for their ideological properties (Baker, 2006; Baker, et al., 2008).

\section{Recent models in (critical) discourse studies}

Figure 1 includes three new approaches in CDS, which had not been acknowledged prior to Hart and Cap's (2014) work. These increasingly influential paradigms can be identified as: Critical Metaphor Analysis (CMA) (Goatly, 2007; Charteris-Black, 2004, 2005; Musolff, 2004, 2016; Zinken, 2007; among others); the cognitive linguistic approach (Chilton, 2004; Hart, 2011, 2013, 2014; Marín Arrese, 2011) - involving, notably, Paul Chilton's (2014) Discourse Space Theory (DST) - and the Legitimization-Proximization Model (LPM) (Cap, 2006, 2013; 2017a; Dunmire, 2011). Although quite similar in their conceptual, cognitive-scientific underpinnings, each of these new models represents, like most strands in CDS, an individual yet interdisciplinary research programme. On top of that, each 
constitutes a specific line of rigorous linguistic inquiry aiming to reveal the otherwise unexplored characteristics of discourse in its socio-political, cultural and anthropological dimensions. Critical Metaphor Analysis, for instance, uses various lexico-grammatical and corpus tools to document the fundamental role that metaphor plays not only in our understanding of the socio-political world we inhabit but also in the way we argue about socio-political issues. Focusing on the qualitative as well as quantitative status of metaphor in public discourse, it shows that metaphorical expressions in language cannot be treated as isolated entities but, rather, as manifestations of knowledge networks in the form of conceptual metaphors, which provide structure and coherence to our experience, including social experience (Goatly, 2007).

The second approach, cognitive linguistic, is more comprehensive and moves beyond metaphor to consider the ideological load of other linguistic structures in terms of the conceptual processes they invoke. It focuses mainly on categorization, spatial representation, and deixis, which bring into effect a range of ideological discursive strategies. At the heart of the cognitive linguistic approach is Discourse Space Theory (Chilton, 2004, 2014), positing that people possess a mental ability to structure their cognitive experience ("looking at" the world) in terms of dichotomous representations of good and evil, right and wrong, acceptable and unacceptable, etc. This ability is linked with a linguistic ability to evoke or reinforce these dichotomous representations in discourse in accordance with people's social goals. The central goal involves getting others to share a common view on what is good-evil, right-wrong, acceptable-unacceptable, etc., and consequently, on how to secure the "right", "good", "useful", "just", against a possible intrusion of the "wrong", "evil", "harmful", etc. Thus, communication nearly always presupposes distance between the Self party (the home group of the speaker) and the Other party (the possible "intruder"). The "good" and "right" are conceptualized and then lexicalized as "close to Self" and the "wrong" and "evil" as peripheral, "remote to Self". Notably for a discourse analyst, the more specific the Self party and the more consequential or broader the goals, the clearer the marking of the distance through linguistic means, for instance deictic expressions.

The Legitimization-Proximization Model (LPM) is more concentrated on a single conceptual operation within discourse space - proximization - and the different forms of its realization (spatial, temporal, axiological) which ensure the continuity of legitimization in a changing social and political context. Like the two other approaches, it considers the ideological and persuasive potential of discourse not as a property of language itself but of the underlying cognitive processes which language reflects and mobilizes. Crucially, LPM subsumes a dynamic conception of discourse space, involving not only the opposition between the Self and the Other (as in DST and CMA), but also the discursively constructed movement of the Other toward the Self. It thus reveals a linguistic focus on the lexical and grammatical deictic choices that speakers make to, first, index existing socio-political and ideological distinctions and, second, demonstrate the capacity of the Other party to erase these distinctions by forcibly colonizing the in-group's space. In that sense, LPM can also be described as a theory of coercion and threat construction. The dynamics of the Self-Other relation is shown in Figure 2, which combines the conceptions of discourse space in the CMA, DST and LPM approaches into a joint representation.

The conception of discourse and discursive space in Figure 2 reveals the focus of the new models on the lexical side of discourse representations. It paves the way for accounting for the Self/Other camps in terms of specific lexical choices involving nominals and nominal phrases. Crucially, it also prompts a lexico-grammatical account (in terms of verbal phrases) of the construed movement (proximization) of the Other toward the Self. Altogether, the research programme promoted by the CMA, DST and LPM models sets them apart from the many other contemporary theories emerging from the CDS family (see Zienkowski, et al., 2011; Angermuller, et al., 2014). Most importantly, it challenges the traditional (Buehler, 1934; Bar-Hillel, 1954; Benveniste, 1966; etc.) view of deixis, on which deictic markers are considered merely a technical necessity for the possible interpretability of a language, rather than an instrument of strategic communication that involves persuasion, legitimization and social coercion. Contesting the conception of deixis as a finite repository of "deictic expressions", the CMA, DST and LPM models take a much broader approach to deictic markers. This new approach posits that the "conventional" deictic items (such as pronominals), which are part of bigger lexico-grammatical phrases and discourse chunks, may be combined with some atypical indexical items (such as complex verb phrases) in those chunks (cf. Table 1 below) to produce elaborate discourse forms responding to the current contextual conditions. As a result, the "component" deictic markers can be treated not just as formal tools for the coding of static elements of context but as essential elements of deictic shifts and 
forced conceptualizations of distance. Naturally, the CMA, DST and LPM models differ with regard to how strongly this position is articulated. Here, Chilton's DST can be considered a precursor, defining the core role of deixis in providing symbolic representation of relative distance in discourse (Chilton, 2004). This account is elaborated upon in the CMA and LPM models. Most crucially, in the recent (Cap, 2013) version of the LPM model, deictic shifts are described in terms of set lexical items and phrases extracted from a corpus. The explanatory powers of the three approaches could thus be regarded as complementary. For instance, while DST and CMA work well in describing the basic architecture of the Discourse Space, i.e. people's established representations and worldviews, the LPM goes on to show how new worldviews can be forced upon by deictic shifts and the reduction of distance between the Self and Other elements of the DS.

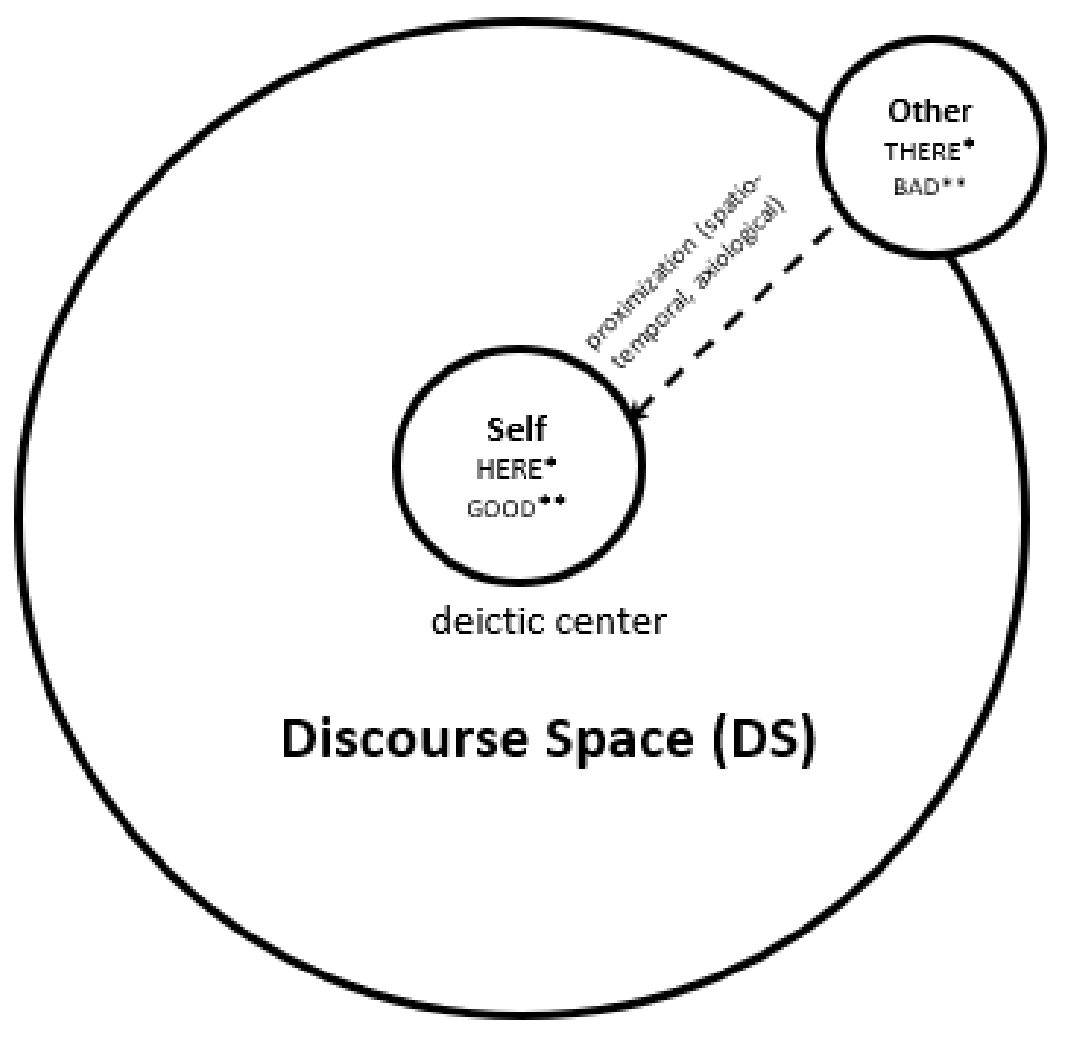

deictic periphery

Figure 2. Architecture of discourse space in the new models of (critical) discourse studies; * centre-periphery opposites in spatio-temporal proximization (including proximization by metaphor) **centre-periphery opposites in axiological proximization (including proximization by metaphor)

There is already quite a number of applications of the CMA, DST and LPM approaches in literature of the field, many involving ideologically charged coercive and legitimization discourses. In his analysis of Polish anti-immigration discourse, Cap (2017b) works with the axiological framework of the LPM model, ${ }^{2}$ categorizing ideological discourse choices in terms of distinct lexico-grammatical items, phrases, and discursive sequences such as those depicted in Table 1. The key part of the axiological framework is its third category, which accounts lexically for a conceptual transition. It marks, in lexical as well as grammatical terms, transformation of the encroachment of Other entities on Self entities, from initially remote and abstract, to close, imminent and material. This change is reflected at the linguistic level in a specific sequence of verbal and nominal elements included in the category. Thus, using the third category of the axiological framework, the discourse researcher can isolate and define, qualitatively and quantitatively, the core language items and formulas which make up the analysed text and the ideological-material transformation.

\footnotetext{
${ }^{2}$ See Cap (2013) for the other two lexico-grammatical frameworks of proximization, spatial and temporal.
} 
Table 1. Axiological proximization framework in the LPM model (after Cap, 2013, 2017b)

\begin{tabular}{|c|c|}
\hline Category & Lexico-grammatical items and phrases \\
\hline 1. Values of elements of the DS deictic centre (Self) & Noun phrases (NPs) marking Self values \\
\hline 2. Values of elements on the DS periphery (Other) & Noun phrases (NPs) marking Other values \\
\hline $\begin{array}{l}\text { 3. Linear logico-rhetorical patterns construing } \\
\text { materialization of antagonistic values of } \text { Other in the } \\
\text { form of Other's physical impact on Self: }\end{array}$ & Discourse sequences comprising: \\
\hline a) remote possibility scenario & Opening verb phrase VP1 containing category $2 \mathrm{NP}$ \\
\hline followed by & followed by \\
\hline b) actual occurrence scenario & $\begin{array}{l}\text { Closing verb phrase VP2 containing an NP marking } \\
\text { Other's physical impact on Self }\end{array}$ \\
\hline
\end{tabular}

In Cap (2017b), the axiological proximization framework is applied in dealing with the anti-immigration rhetoric of the Law \& Justice (L\&J) party, which has been in power in Poland since its victory in parliamentary elections in October 2015. The study draws on a corpus of addresses, statements and comments by the most prominent L\&J politicians, including Jarosław Kaczyński (the L\&J leader), Beata Szydło (prime minister of the L\&J government, 2015-2017), and Mariusz Błaszczak (interior minister, 2015-2017). The analysis involves, among others, the following examples:

(1) Our position has been clear from the beginning. The issue of immigration from the Middle East should be resolved where it has originated. By advancing freedom and democracy in Syria and Iraq, we help end a cycle of dictatorship and radicalism that brings millions of people to misery and frustration, and brings danger and, one day, tragedy, to our home and own people. (Beata Szydło, October 3, 2016)

(2) To those who are happy to welcome immigrants at our doors, I have a suggestion: go and see the refugee camps in Turkey. See the gangs and the riots. See the young Muslim criminals. See the anger, violence, and terror. It is there and is ready for export. This evil might not have reached us yet, but it is well in sight. And there is no-one in Brussels who can protect us when it comes. (Mariusz Błaszczak, February 13, 2017) ${ }^{3}$

Cap's (2017b, p. 295) study acknowledges an explicit link in (1) between the social and political conditions which underlie lives of potential immigrants in their home countries ("Syria and Iraq"), and the socio-psychological effects ("misery and frustration") which may bring about disastrous consequences later on, after the immigrants' arrival in Poland ("one day, tragedy, to our home and our own people"). This argument helps legitimize the anti-immigration stance and policies of the L\&J government, by advancing the rationale for handling the immigration issue far away from Poland's borders (latterly metaphorized as "home"). The argument unfolds in a linear manner, connecting apparently remote visions with, eventually, recently occurring events. At the lexico-grammatical level, nominal phrases are used to denote the Self vs. Other (ideological) opposition ("our people" vs. people living in "dictatorship and radicalism"), and verbal phrases ("brings millions of people", "brings danger") are applied to proximize Other's anticipated impact. Altogether, the argument and its transition from the "remote possibility scenario" to the "actual occurrence scenario" involve two nominal chunks and two verbal ones, as the axiological framework in Table 1 has it.

A similar arrangement is observed in (2), where transition between the two scenarios involves a change in the modality of the text. While the opening verbal chunk (VP1, in terms of the axiological

\footnotetext{
${ }^{3}$ The examples have been re-numbered from the original numbers 9 and 10 (Cap, 2017b, pp. 295-296). The boldface indicates the elements/values/actions associated with the Self camp in deictic centre. The italicized boldface indicates the elements/values/actions associated with the Other camp on deictic periphery.
} 
framework) construes conditions for a possible impact ("is ready for export"), the closing chunk (VP2) construes this impact as well under way and already perceptible from the Self camp ("is well in sight"). Cap (2017b, p. 296) illustrates the dynamics of such a two-step conceptual proximization in the following way (Figure 3):

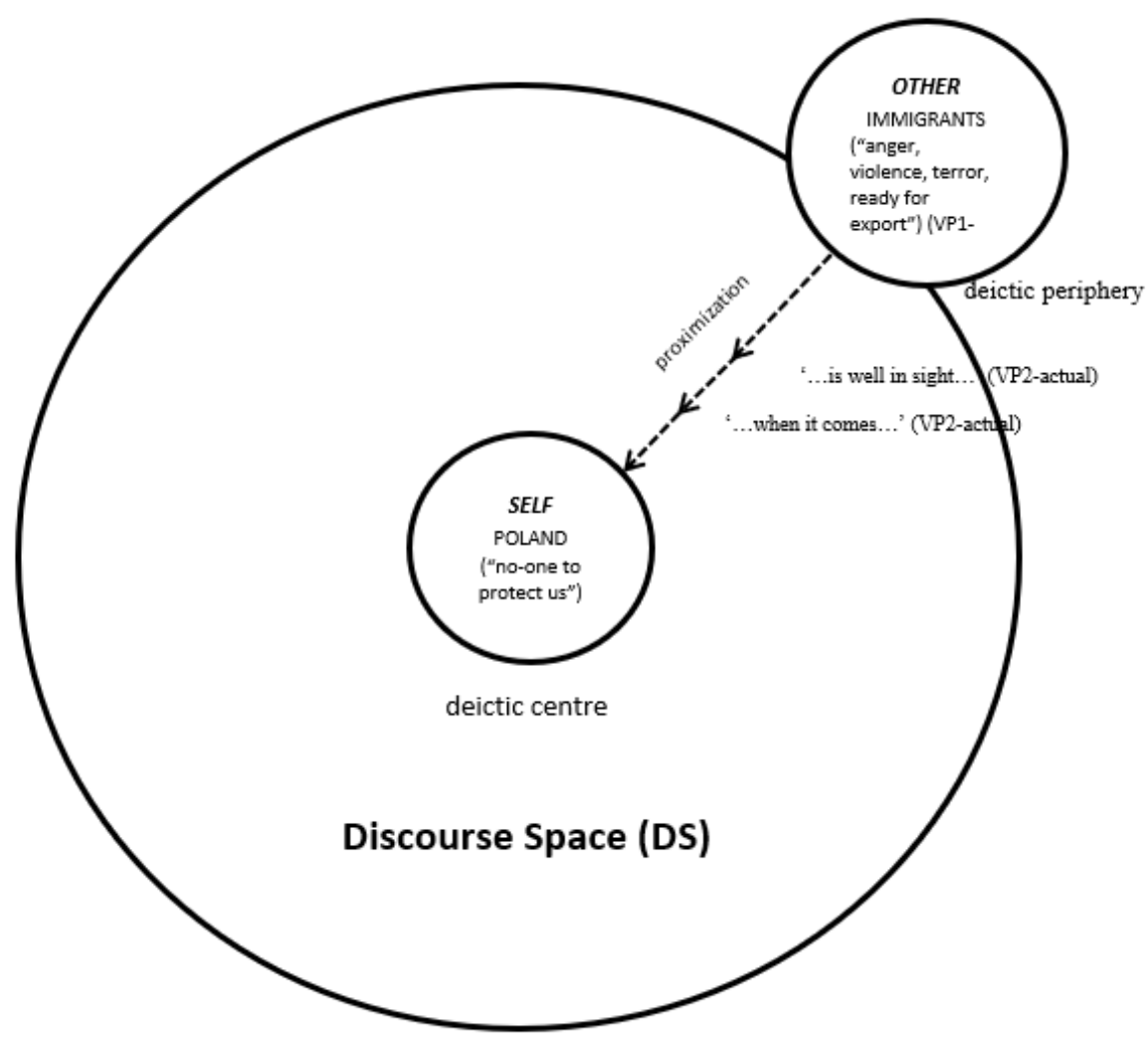

Figure 3. Proximization in Discourse Space (DS) in example (2) [Cap 2017b, p. 296, Figure 3]

Still, as Cap (2017b, p. 296) notes, the argument in (2) reveals some differences. Specifically, the origin, or source, of the encroachment is very different, in geographical and geopolitical terms. The (Muslim) immigrants are geographically closer, and they are construed as inherently evil, rather than negatively affected. The Self/Other opposition is thus more acute, the conflict more ominous ("anger, violence, and terror [are there] ready for export"), and the envisaged effects more destructive, partly because of the characteristics of the invader, and partly because of the vulnerability of the home camp ("no-one in Brussels who can protect us when it [evil] comes"). Such a radical stance, goes Cap's (2017b) analysis, can be seen in multiple speeches and statements of L\&J politicians, and is often reinforced by examples of Western countries' negligence leading to tragic events. The comments in (2) come from a parliamentary debate on immigration and are a direct follow-up on a comment from another L\&J MP about identifying the perpetrator of the Nice terrorist attack (in July 2016) as a Muslim refugee. This rhetorical strategy, focused upon the apparent lack of political responsibility of the European Union, complements the simple fear appeals that rest in descriptions of previous criminal acts committed by immigrants.

The excerpts from Cap's (2017b) work, though necessarily brief and synthetic, reveal the focus of the new discourse models - such as CMA, DST, and LPM - on systematic, text-analytical exploration of discourse based upon a variety of linguistic tools: lexical and grammatical patterns, modality features, and syntactic structure. Following this agenda, many researchers have attemped to design their own domain-specific methodologies to extract, analyse and interpret different portions of quantifiable discourse data. For example, Dunmire (2011) extends the analytical range of the LPM model to make it account for different functions of analogies and historical flashbacks in state-level political discourse in 
terms of different kinds and numbers of lexical markers of temporal proximization. Within DST, Kaal (2015) works on the spatial aspect of the Self/Other categories, to express their location and relative distance in terms of frequencies of lexical forms marking opposing entities. And in CMA, huge advances are being made in corpus-based research of the patterning of linguistic metaphor, creating findings in variation in metaphor use across different registers and communicative genres. While all these studies share the central commitment to (critical) discourse research to bring to light hitherto unexplored characteristics of ideologically charged discourse, there is an ever-growing number of domains where this commitment is being realized. Apart from the cradle domain of political discourse, recent foci involve several prominent public discourses of today such as health, environment, education, modern technology, and others. A comprehensive overview of the most recent work in these domains is presented in Flowerdew and Richardson (2018).

\section{Conclusion}

Questions surrounding the evolution of discourse studies (DS) over the last 30-35 years are not apparently very different from the central questions in language philosophy. Indeed, DS (and CDS) has to deal with a number of core ontological and epistemological issues linking various aspects of language, reality, and mentality. What is the relationship between language and the world? What is the relationship between language and the mind? In DS, these questions are invariably addressed within and against the context of two stable points of reference. One is the social side and power potential of language - its social constructionism - the residing potential to reflect, define, and redefine social distinctions. The other is discourse itself, its linguistic capacity to index, prescribe and sanction (often institutionally) these distinctions. While the former perspective is largely abstract in nature, the latter is concrete; it involves specific language resources as well as ways to identify and interpret them.

In the development of discourse studies, the relationship between these two points, or perspectives, has never been stable. This can partly be attributed to differences in the development of the source methodological terrains - social sciences and linguistics. Seemingly, only the modern advances in many branches of linguistics (e.g. anthropological and clinical linguistics) made it possible to address certain issues such as the persuasive or otherwise coercive load of discourse. It has taken some time, too, for sociologists, socio-political scientists, culture researchers, etc., to reconcile their classical analytical traditions with the new methods and tools. As noted by Jessop and Sum (2018), classical discourse theories indeed offer a lot in terms of theoretical premises; yet they fail to provide any empirical handles. This can certainly be observed in Laclau and Mouffe's DT: while the idea of "discursive struggle" provides for a rich conception of intertextual and interdiscursive meaning, no hint is given as to the domains in which to endorse such a conception.

Still, the last three decades have seen a gradual consolidation of social and linguistic perspectives. This means, at the same time, consolidation of the three main discourse ontologies, or views of discourse: discourse as text, discourse as discursive practice, and discourse as social practice. Here, much of the credit goes without doubt to the thriving CDS movement. This is not merely because CDS scholars work at the intersection of social theory and linguistic frameworks. The really important thing is that many CDS scholars are happy to revisit and re-focus the existing models of language (often classical models, such as Halliday's systemic functional grammar) to meet the needs of socially motivated discourse analysis. As a result, new analytical frameworks are created, equipped with lexical and structural tools to handle the linguistic aspect of discourse processes.

The three approaches discussed in the last section of this paper are just a sample of these new developments. Discourse studies today is a huge industry, comprising hundreds of journals and tens of thousands printed book pages daily. It is fed, also daily, by momentous socio-political events and their countless representations in all forms of institutionalized and social media. Given this influence, it would be naïve to see modern discourse studies as a completely "unpolitical" enterprise; even Martin and Rose's (2003) "positive" project is essentially political. What one can hope, however, is that data analysis and hard evidence brought to discourse studies by the linguistic models of discourse (such as DST and its developments) keep any politics there to a minimum.

\section{References}

Althusser, L., 1971. Lenin and philosophy and other essays. New York: Monthly Review Press. 
Angermuller, J., Maingueneau, D. and Wodak, R. (eds), 2014. The discourse studies reader. Main currents in theory and analysis. Amsterdam: Benjamins.

Baker, P., 2006. Using corpora in discourse analysis. London: Continuum.

Baker, P., Gabrielatos, C., KhosraviNik, M., Krzyżanowski, M., McEnery, T. and Wodak, R. 2008. A useful methodological synergy? Combining critical discourse analysis and corpus linguistics to examine discourses of refugees and asylum seekers in the UK press. Discourse \& Society, vol. 19, no. 3, pp. 273-306.

Bakhtin, M., 1981. The dialogic imagination. Edited by M. Holquist. Austin: University of Texas Press. Bar-Hillel, Y., 1954. Indexical expressions. Mind, vol. 63, pp. 359-379.

Benke, G., 2000. Diskursanalyse als sozialwissenschaftliche Untersuchungsmethode. SWS Rundschau, vol. 2, pp.140-162.

Benveniste, E., 1966. Problemes de linguistique gènêrale 1. Paris: Gallimard

Blommaert, J. and Bulcaen, C., 2000. Critical Discourse Analysis. Annual Review of Anthropology, vol. 29, no. 4, pp. 447-466.

Bourdieu, P., 1992. Language and symbolic power. Cambridge: Polity Press.

Breeze, R., 2011. Critical Discourse Analysis and its critics. Pragmatics, vol. 21, no. 3, pp. 493-525.

Buehler, K., 1934. Sprachtheorie. Die Darstellungsfunktion der Sprache. Stuttgart: Fischer.

Cap, P., 2006. Legitimization in political discourse. Newcastle: CSP.

Cap, P., 2013. Proximization: The pragmatics of symbolic distance crossing. Amsterdam: Benjamins.

Cap, P., 2017a. The language of fear: Communicating threat in public discourse. Basingstoke: Palgrave.

Cap, P., 2017b. From 'cultural unbelonging' to 'terrorist risk': Communicating threat in the Polish antiimmigration discourse. Critical Discourse Studies, vol. 15, no. 3, pp. 285-302.

Cap, P. and Okulska, U. (ed.), 2013. Analyzing genres in political communication: Theory and practice. Amsterdam: Benjamins.

Charteris-Black, J., 2004. Corpus approaches to Critical Metaphor Analysis. Basingstoke: Palgrave.

Charteris-Black, J., 2005. Politicians and rhetoric: The persuasive power of metaphor. Basingstoke: Palgrave.

Chilton, P., 2004. Analysing political discourse: Theory and practice. London: Routledge.

Chilton, P., 2005. Missing links in mainstream CDA: Modules, blends and the critical instinct. In: R. Wodak and P. Chilton, eds. A new agenda in (Critical) Discourse Analysis. Amsterdam: Benjamins, pp. 19-51.

Chilton, P., 2014. Language, space and mind: The conceptual geometry of linguistic meaning. Cambridge: Cambridge University Press.

Chouliaraki, L. and Fairclough, N., 1999. Discourse in late modernity. Rethinking Critical Discourse Analysis. Edinburgh: Edinburgh University Press.

Derrida, J., 1970. Structure, sign, and play in the discourse of the human sciences. In: R. Macksey and E. Donato, eds. The languages of criticism and the sciences of man. Baltimore, MD: John Hopkins University Press, pp. 247-272.

Dunmire, P., 2011. Projecting the future through political discourse: The case of the Bush Doctrine. Amsterdam: Benjamins.

Fairclough, N., 1989. Language and power. London: Longman.

Fairclough, N., 1992. Discourse and social change. Cambridge, MA: Polity Press.

Fairclough, N., 1995. Critical Discourse Analysis. London: Longman.

Fairclough, N. and Wodak, R., 1997. Critical discourse analysis. In: T. van Dijk, ed. Discourse as social interaction. London: Sage, pp. 258-284.

Fetzer, A., 2018. Discourse analysis. In: A.H. Jucker, K.P. Schneider and W. Bublitz, eds. Methods in pragmatics (Handbooks of Pragmatics, Volume 10). Berlin: Mouton de Gruyter, pp. 401-421.

Flowerdew, J. and Richardson, J. (eds), 2018. The Routledge handbook of Critical Discourse Studies. London: Routledge.

Foucault, M., 1971. L'ordre du discours. Paris: Gallimard.

Foucault, M., 1972. The archeology of knowledge and the discourse on language. Translated by A. M. Sheridan. New York: Pantheon.

Fowler, R., Kress, G. and Trew, T., 1979. Language and control. London: Routledge.

Fowler, R., 1991. Language in the news. London: Routledge.

Giltrow, J. and Stein, D. (eds), 2009. Genres in the Internet. Amsterdam: Benjamins. 
Goatly, A. 2007. Washing the brain: Metaphor and hidden ideology. Amsterdam: Benjamins.

Golato A. and Golato, P., 2018. Ethnomethodology and conversation. In: A.H. Jucker, K.P. Schneider and W. Bublitz, eds. Methods in pragmatics (Handbooks of Pragmatics, Volume 10). Berlin: Mouton de Gruyter, pp. 380-399.

Gramsci, A., 1973. Selections from the prison notebooks of Antonio Gramsci. New York: International Publishers.

Halliday, M. A. K., 1978. Language as social semiotic: The social interpretation of language and meaning. London: Edward Arnold.

Halliday, M. A.K., 1994. Introduction to functional grammar. London: Arnold.

Hart, C., 2011. Moving beyond metaphor in the Cognitive Linguistic Approach to CDA: Construal operations in immigration discourse. In: C. Hart, ed. Critical discourse studies in context and cognition. Amsterdam: Benjamins, pp. 171-192.

Hart, C., 2013. Event-construal in press reports of violence in political protests: A cognitive linguistic approach to CDA. Journal of language and politics, vol. 12, no. 3, pp. 400-423.

Hart, C., 2014. Discourse, grammar and ideology: Functional and cognitive perspectives. London: Bloomsbury.

Hart, C. and Cap, P. (eds), 2014. Contemporary Critical Discourse Studies. London: Bloomsbury.

Hodge, R. and Kress, G., 1993. Language as ideology. London: Routledge.

Jessop, B. and Sum, Ngai-Ling., 2018. Language and critique: Some anticipations of critical discourse studies in Marx. Critical Discourse Studies, vol. 15, no. 2, pp. 325-337.

M. Jørgensen and Phillips, L., 2002. Discourse Analysis as theory and method. London: Sage.

Kaal, B., 2015. How 'real' are time and space in politically motivated worldviews? Critical Discourse Studies, vol. 12, no. 3, pp. 330-346.

Koller, V., 2004. Metaphor and gender in business media discourse: A critical cognitive study. Basingstoke: Palgrave.

Lacan, J., 2007. The seminar of Jacques Lacan, Book XVII: The other side of psychoanalysis. Translated by R. Grigg. London: Norton.

Laclau, E., 1990. New reflections on the revolution of our time. London: Verso.

Laclau, E., 1993. Power and representation. In: M. Poster, ed. Politics, theory and contemporary culture. New York: Columbia University Press, pp. 14-45.

Laclau, E., 1996. The death and resurrection of the theory of ideology. Journal of political ideologies, vol. 1, pp. 201-220.

Laclau, E. and Mouffe, C., 1985. Hegemony and socialist strategy: Towards a radical democratic politics. London: Verso.

Lakoff, G. and Johnson, M., 1980. Metaphors we live by. Chicago: University of Chicago Press.

Luke, A., 2002. Beyond science and ideological critique: Developments in critical discourse analysis. Annual review of applied linguistics, vol. 22, no. 1, pp. 96-110.

Macgilchrist, F., 2014. Media discourse and de/coloniality. A post-foundational approach. In: C. Hart and P. Cap, eds. Contemporary Critical Discourse Studies. London: Bloomsbury, pp. 385-405.

Marin Arrese, J., 2011. Effective vs. epistemic stance and subjectivity in political discourse: Legitimising strategies and mystification of responsibility. In C. Hart, ed. Critical discourse studies in context and cognition. Amsterdam: Benjamins, pp. 193-224.

Martin, J. R., 2004. Positive discourse analysis: Solidarity and change. Revista canaria de estudios Ingleses, vol. 49, pp. 179-202.

Martin, J. R. and Rose, D., 2003. Working with discourse: Meaning beyond the clause. London: Continuum.

Mouffe, C. (ed.), 1993. The return of the political. London: Verso.

Musolff, A., 2004. Metaphor and political discourse: Analogical reasoning in debates about Europe. Basingstoke: Palgrave.

Musolff, A., 2016. Political metaphor analysis: Discourse and scenarios. London: Bloomsbury.

O'Halloran, K., 2010. How to use corpus linguistics in the study of media discourse. In: A. O'Keeffe and M. McCarthy, eds. The Routledge handbook of corpus linguistics. Abingdon: Routledge, pp. 563-576. 
Partington, A., 2006. Metaphors, motifs, and similes across discourse types: Corpus assisted discourse studies (CADS) at work. In: A. Stefanowitsch and S. Gries, eds. Corpus-based approaches to metaphor and metonymy. Berlin: Mouton de Gruyter, pp. 267-304.

Phillips, N. and Hardy, C., 2002. Discourse analysis: Investigating processes of social construction. London: Sage.

Reisigl, M. and Wodak, R., 2001. Discourse and discrimination: Rhetorics of racism and anti-semitism. London: Routledge.

Saussure, F. de., 1966. Course in general linguistics. New York: McGraw-Hill.

Stubbs, M., 1997. Whorf's children: Critical comments on critical discourse analysis. In: A. Ryan and A. Wray, eds. Evolving models of language. Clevedon: Multilingual Matters, pp. 100-116.

Stubbs, M., 2002. Two quantitative methods of studying phraseology in English. International Journal of Corpus Linguistics, vol. 7, no. 2, pp. 215-244.

Stubbs, M., 2004. Language corpora. In: A. Davies and C. Elder, eds. Handbook of applied linguistics. Oxford: Blackwell, pp. 106-132.

Unger, J., 2016. The interdisciplinarity of critical discourse studies research. Palgrave Communications, vol. 2: 15037.

Van Dijk, T., 1999. Critical Discourse Analysis and Conversation Analysis. Discourse \& Society, vol. 10, no. 4, pp. 459-470.

Van Dijk, T., 2008. Discourse and context: A socio-cognitive approach. Cambridge: Cambridge University Press.

Van Eemeren, F. and Grootendorst, R., 1992. Argumentation, communication, and fallacies. A pragmadialectical perspective. Hillsdale, NJ: Lawrence Erlbaum.

Van Leeuwen, T., 2005. Introducing social semiotics. London: Routledge.

Widdowson, H., 1998. The theory and practice of Critical Discourse Analysis. Applied Linguistics, vol. 19 , no. 1, pp. 136-151.

Widdowson, H., 2005. Text, context, pretext: Critical issues in discourse analysis. Oxford: Blackwell.

Wodak, R., 2011. Critical linguistics and critical discourse analysis. In: J. Zienkowski, J-O Ostman and J. Verschueren, eds. Discursive pragmatics. Amsterdam: Benjamins, pp. 50-70.

Wodak, R. (ed.), 2012. Critical Discourse Analysis (4 volumes). London: Sage.

Wodak, R. and Meyer, M. (eds), 2016. Methods of critical discourse analysis. London: Sage.

Yus, F., 2011. Cyberpragmatics: Internet-mediated communication in context. Amsterdam: Benjamins.

Zienkowski, J., Östman, J-O. and Verschueren, J. (eds), 2011. Discursive pragmatics. Amsterdam: Benjamins.

Zinken, J., 2007. Discourse metaphors: The link between figurative language and habitual analogies. Cognitive Linguistics, vol.18, no. 3, pp. 445-466. 